\title{
Distance Learning in the Musical Field in Romania through European-Funded Projects
}

\author{
https://doi.org/10.3991/ijac.v11i1.9209 \\ Nelida Nedelcut ${ }^{1}$, Ciprian Gabriel Pop ${ }^{2}$ and Amalia Cristina Nedelcuț ${ }^{3}$ \\ 1,2 Academy of Music Gheorghe Dima/Department of Distance Education, Cluj-Napoca, Romania \\ Babes-Bolyai University, Faculty of Economics and Business Administration/Management Department, Cluj-Napoca, \\ Romania
}

\begin{abstract}
The organization of Romanian distance learning in music has been supported in terms of research, collaboration and financing by European projects, with the following achievements: training of teaching staff involved in distance learning, assistance in activities meant to introduce ICT in general schools, construction of a platform dedicated to distance learning activities, creating a database with instrumental accompaniments for singers, designing multimedia courses, assessing distance learning programs offered by the Academy of Music Gheorghe Dima in ClujNapoca.
\end{abstract}

The Prelude Training Program on ICT in Music Education - a project aimed at developing a training program for inservice music educators, as there are many ways in which technology helps educators meet instructional goals: Programs designed to help students develop their musicianship or improve their knowledge of notation and skill in reading notation, support with improvisation skills, notation and sequencing programs which assist students in composition activities.

Vemus - Virtual European Music Schools - a program which focuses on teaching music notation or performing instruments, involving execution of rhythm patterns, melody, music scores; E-vocal learning, with simultaneous appearance of sound and notation, conducted by famous musicians. DIMA - Direct Impact of Multimedia Application - a platform that comprises courses, audio and video examples focusing on music history, performing and listening activities.

The partners proceed from various areas (higher education, innovation/development centers), and the projects were conceived to stimulate the implementation of ICT in the educational process in music, approaching teaching staff as a target group, and students as an interested party.

The need for such products was revealed by interviews and questionnaires and the results' evaluation proved that the online environment can be accessed in order to develop educational resources, enrich lesson content, motivate and engage children in music education, deliver information and learning opportunities, stimulate children in their musical endeavors.

Index Terms-EU project, educational platform, training teachers, music, Romanian dissemination, IT magazine, multimedia applications, national grants.

\section{INTRODUCTION}

The introduction of information and communication technology in music has created interdisciplinary fields that have subsequently established a basis for various disciplines such as: musicology, computer-assisted composition, acoustics, sound processing, psychoacoustics, interfering to an equal extent with principles from physics, electronics, informatics, and social sciences. In current electronic music, as the virtualization of the work environment increases with every day that goes by, the tools most frequently used are computer software and software suites which offer media for recording, synthesis, manipulation, arrangement of the audio material beside the usual hardware found in studios. One of the most important advantages of using the virtual environment is the fact that, on the whole, everything is cheaper and much more versatile (1). The market is literally flooded with a range of software and software suites that can be used to create music, the number and the features of which can be confusing. Nevertheless, a careful analysis of all these tools can reveal a series of mutual elements which, once assimilated, can establish a starting point in learning how to use them (2).

Music education through the use of ICT posed a challenge for all institutions due to the complexity of the methods and processes involved in the system, and the solutions offered in various European countries were the result of research and experiments validated by notable outcomes [3], [4], [5], [6]. Various perspectives in the use of information and communication technology triggered the development of learning methods such as creative and collaborative learning, which have had a very dynamic evolution, each year bringing about innovations and improvements. The directions pursued by the endeavors of experts in the field of music focused on the impact of ICT in music education, designing specialized software [7] as well as educational platforms targeted at a range of users from novice students to professional musicians [8]. The topic of distance learning has become a highly current issue and has been developed in European projects which finance new methods and techniques specific to the field of music and study the impact of distance learning in education. A higher number of complete courses and entire degree programs in music education have thus become accessible [9]. In order to motivate people to introduce ICT in music education, it is recommended to access the 
online environment for the accomplishment of the following purposes:

- Development of educational resources;

- Enrichment of lesson content by accessing information on-line;

- Motivation and engagement of children in music education;

- Provision of information and learning opportunities in ways that are attractive to children;

- Stimulation of children to perform their own musical investigations [10].

In Romania, the challenges faced in introducing this type of education were linked to insufficient knowledge of using ICT materials by educators, on the one hand, and, on the other hand, to the inexistence of data bases that would have facilitated the planning of a building process for an IT-based educational system in music. The introduction of distance learning in the field of music in Romania benefited by the experience of prestigious European institutions; the need for a rapid implementation of the educational methods specific to this type of education determined the Academy of Music Gheorghe Dima (AMGD), as an institution accredited for the provision of undergraduate programs in the form of distance learning, to approach effective teaching/learning techniques. The high number of unqualified teaching staff who were providing teaching or artistic activities in various institutions motivated AMGD to organize music education programs by distance learning and, to this end, to have its own staff trained in the use of information technology and to create workplaces in order to receive an education.

The undergraduate programs have attracted numerous people in search of a qualification, leading to a continuous request for distance learning education over the past ten years.

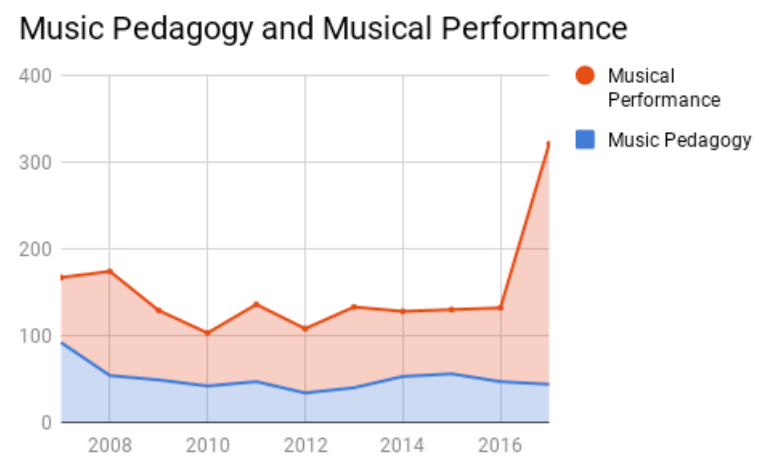

Figure 1. The dynamics of students enrolled in distance learning programs in AMGD

In the construction stages of the undergraduate programs the teaching staff attended numerous training courses meant to teach them how to create learning materials. The infrastructure necessary for the development of distance learning programs in AMGD was provided by means of a research project financed by the World Bank. The access to European research networks in the field of ICT in music enabled participants to get acquainted with the features of the e-learning system and the opportunities of adapting it to the musical field. Between 2006 and 2014 the institution received European funding as partner or subcontractor, in projects that made a considerable contribution to the construction of distance learning in the musical field in Romania, such as:

TABEL I

EUROPEAN PROJECTS

\begin{tabular}{|c|c|c|}
\hline PROJECT & $\begin{array}{l}\text { Financing } \\
\text { line/subject }\end{array}$ & Partners \\
\hline $\begin{array}{l}\text { Prelude - } \\
\text { Training } \\
\text { Program on ICT } \\
\text { in Music } \\
\text { Education } \\
\text { SOCRATES } \\
\text { COMENIUS } \\
\text { 2.1 Action } \\
\text { (Training of } \\
\text { School } \\
\text { Education Staff) }\end{array}$ & $\begin{array}{l}\text { A training EU } \\
\text { program on } \\
\text { ICT in Music } \\
\text { Education } \\
\text { higher } \\
\text { education, } \\
\text { innovation/ } \\
\text { development } \\
\text { centre }\end{array}$ & $\begin{array}{l}\text { Ellinigermaniki Agogi } \\
\text { (GR), Roehampton } \\
\text { University (UK), } \\
\text { Enterprise Walding } \\
\text { (AT), Sonic Interactive } \\
\text { Institute (SE), Centre of } \\
\text { Innovation, Academy of } \\
\text { Music Gh. Dima (RO), } \\
\text { Institution Sek } \\
\text { Ciudalcampo (ES), } \\
\text { Miksike (EE). }\end{array}$ \\
\hline $\begin{array}{l}\text { Vemus -Virtual } \\
\text { European } \\
\text { Music Schools } \\
\text { Framework } \\
\text { Program } 6 \\
\text { (Technologies } \\
\text { for the } \\
\text { Information } \\
\text { Society - IST). }\end{array}$ & $\begin{array}{l}\text { Virtual } \\
\text { instruments, } \\
\text { psychoacoustics, } \\
\text { Artificial } \\
\text { Intelligence, and } \\
\text { Human- } \\
\text { Computer } \\
\text { Interaction. }\end{array}$ & $\begin{array}{l}\text { Institute for Language } \\
\text { and Speech Processing } \\
\text { (GR), Centre National } \\
\text { de Creation Musicale } \\
\text { (FR), Royal Institute of } \\
\text { Technology (SE), } \\
\text { Ellinigermaniki Agogi } \\
\text { (GR), Balteck (LT), } \\
\text { Philippos Nakas S.A. } \\
\text { (GR), Miksike Learning } \\
\text { Folders Ltd. (EE), } \\
\text { Centrul pentru } \\
\text { Dezvoltare şi Inovare în } \\
\text { Educaţie (RO). }\end{array}$ \\
\hline $\begin{array}{l}\text { E-vocal } \\
\text { learning } \\
\text { Lifelong } \\
\text { Learning, } \\
\text { Program } \\
\text { Creativity and } \\
\text { Innovation }\end{array}$ & $\begin{array}{l}\text { Design of an e- } \\
\text { learning } \\
\text { platform for } \\
\text { singing on the } \\
\text { web }\end{array}$ & $\begin{array}{l}\text { Vokalakademie (AT), } \\
\text { Concorde International } \\
\text { (U), Fachhochschule } \\
\text { Wedel (DE), } \\
\text { Rózsavölgyi Márk } \\
\text { Müvészeti Iskola (HU), } \\
\text { VHS Poly College, } \\
\text { Wiener Volksbühne } \\
\text { (AT) }\end{array}$ \\
\hline $\begin{array}{l}\text { Dima } \text {-Direct } \\
\text { Impact of } \\
\text { Multimedia } \\
\text { Application- } \\
\text { Exploratory } \\
\text { research project } \\
\text { PN II Idei }\end{array}$ & $\begin{array}{l}\text { Exploration of } \\
\text { the adaptation of } \\
\text { on-line } \\
\text { educational } \\
\text { materials to } \\
\text { music teaching; }\end{array}$ & $\begin{array}{l}\text { Academy of Music } \\
\text { Gheorghe } \\
\text { Dima (RO). }\end{array}$ \\
\hline
\end{tabular}

\section{PRELUDE PROJECT OVERWIEW}

Prelude was an EU project that provided mainly a training program for in-service music teachers. The main target was to stimulate the implementation of IT in the teaching/learning process in the music education area. The project milestones:

- The preliminary survey consisted in: interviews held with the selected teachers and questionnaires addressed to music teachers of the consortium, then drafting a synoptic table concerning the music education system in the partners' countries;

- The Prelude training program with conventional courses and workshops; 
- The creation of the Prelude distance learning platform

The initial inquiry, organized in order to identify "The teachers' needs" highlighted various shortcomings and training needs in the participant countries. The conclusion was that each partner of the consortium must organize teacher training according to their own training plan. In AMGD, we applied the following evaluation tools:

a) interviews held with the selected teachers (teachers of theory and musical instruments)

b) two questionnaires applied to 25 teachers; the first questionnaire comprised 12 questions focusing on the evaluation of ICT degrees, and the second had 10 questions aiming at identifying the evolution trend of IT in the following five years. This highlighted necessities linked to the following shortcomings:

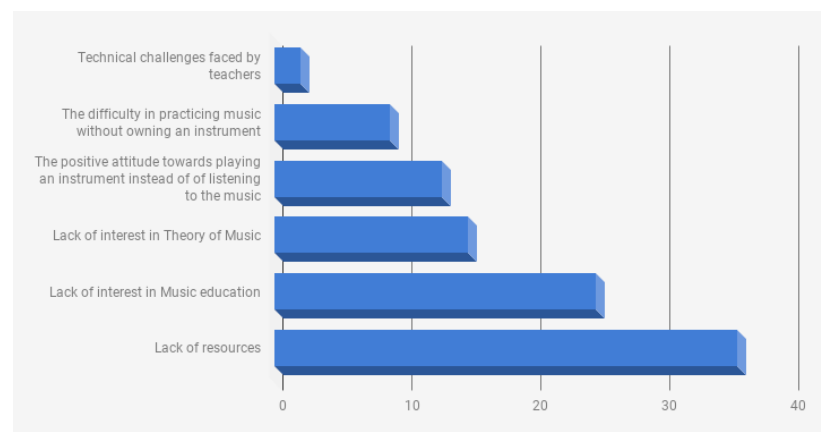

Figure 2. The problems encountered in the educational process

The main result of the project was connected with the opportunity to train teaching staff from each participant institution based on a training program for in-service music teachers created by the experienced institutions in the project, in which technology sought to address the instructional goals of music teachers in each particular country. These include: programs designed to help students develop their musicianship or improve their knowledge of notation and skill in reading notation or improvisation skills, simultaneous appearance of sound and notation, programs which focus on teaching music notation or performing aural tests involving recognition and dictation of rhythm patterns, melody patterns, musical intervals, chord sequences and harmonic progressions, notation and sequencing programs which assist students in composing activities.

An electronic platform based on Moodle was launched, with the following facilities:

- Search the list of courses

- Have access to materials in various formats (text, video, audio, link on the web)

- Edit or update profiles

- Download teacher assignments

- Reflect on proposed materials and upload feedback

- Use the communication facilities

- Present students' own questions and answers

- Get informed about events, news or class activities

- Participate in the assessment
The PRELUDE project represents a paradigm of the distance education plan that seeks to employ the advantages of Open and Distance Learning (ODL) instruments and techniques in order to provide:

- Quality in service training to music teachers

- Professional support to trainees

- Testing and reflective feedback on suggested teaching activities

- Formation of groups and communities amongst the participants

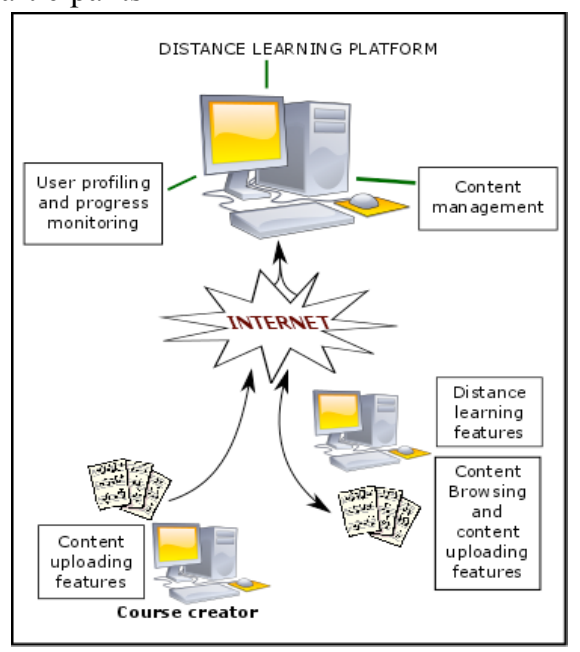

Figure 3. Prelude Platform chart

Prelude Platform was based on the Moodle (acronym for Modular Object-Oriented Dynamic Learning Environment) free educational software package - an excellent open source and free Learning Management System. Moodle was chosen because of its functionalities that include: Multi-lingual choice, not specific hardware requirements, respect for international learning standards, personalization for the learner, easy installing and managing, detailed monitoring for students, tools for content creation, assessment for the students, various forms of communication, etc. - all with the advantage of free software status.

TABLE II

PRELUdE PROJECT OUTPUTS

\begin{tabular}{|l|c|}
\hline Project products & Accomplishments of AMGD \\
\hline a) a platform (web page for & $\begin{array}{c}\text { access to experience in the } \\
\text { personal projects, links } \\
\text { connected to similar sites }\end{array}$ \\
and libraries online), and a & countries; in European \\
bulletin/newsletter (PRELUDE & training of Romanian teaching \\
training platform); & staff in using electronic \\
b) a guide of good practice & platforms and ICT in music \\
issued in electronic and classic & classes; \\
format, disseminated & specialization of the tutors and \\
among all interested people; & coordinators involved in the \\
c) editing a CD containing this & distance learning activities \\
guide, as well as the latest & in AMGD; \\
edition of the project's web & assistance from specialists in \\
page (PRELUDE CD-ROM). & activities linked to the \\
& introduction of ICT in \\
& general schools; \\
& construction of an interactive \\
& platform dedicated to \\
& distance activities \\
\hline
\end{tabular}


After organizing training workshops for teachers in several schools in Romania, they showed interest in becoming acquainted with and using ICT in music classes. The access to the Prelude information base also led to the specialization of coordinators and tutors from AMGD, who subsequently contributed to building the distance learning system in the institution.

After finalizing the project, the training of teaching staff in the use of ICT in the musical field continued, as AMGD organized training programs meant to integrate ICT on two levels:

- training courses for the tutors and coordinators in the institutions (2/year)

- research projects in IT, for example exploration of the adaptation of on-line educational tools to the artisticmusical education, a project financed by the Ministry of Research in Romania.

\section{VIRTUAL EUROPEAN MUSIC SCHOOL}

VEMUS is the acronym for Virtual European Music School, a project which seeks to design, develop, implement and evaluate a virtual educational environment destined for learning to play wind instruments: the flute, the saxophone, the clarinet, and the recorder. The platform addressed beginners and mediumlevel learners and proposed interactive methods for:

- individual practice, where the online evaluation of a student's performance was possible not only during the exercise, but also after its conclusion, due to a complete feedback;

- study in the classroom, offering support instruments for teachers in the process of teaching music in groups in the classroom. That was possible with the help of the automatic administration of the network resources of VEMUS, which enable the use of the wireless capacities of laptops or tablets for setting up peer to peer networks without the need for any special configurations;

- distance learning, the VEMUS platform offers a collection of music exercises and assignments, enable the improvement of students' skills, instruments for the creation of new content as well as means of communication and collaboration which enable distance tutoring activities and the monitoring of the students' progress.

By incorporating the three learning modes into an integrated educational environment, we sought to combine virtual activities and traditional ones, creating the technological and pedagogical premises for a virtual platform dedicated to students and teachers throughout Europe: the Virtual European Music School [11]. The VEMUS project was based on the field research and the platform developed during the IMUTUS project [12], an interactive learning platform. Dedicated to students aged 9-15, the platform was devised as a support for the teaching and learning process, supporting both independent and collaborative practice. It offers the possibility to play a piece, listen to a reference recording thereof, then to record student performances, and submit these for evaluation. Students are offered an evaluation of their own performance, in order to guide practice towards the elements that need correction. More specifically, VEMUS provides the possibility to practice on specific musical pieces and hear reference recordings. This project started from an organized survey that indicated the existence of a necessity for such an educational system since, according to the outcomes, $88 \%$ of the responding students have access to a computer at home, while $69 \%$ of them believe that the computer could assist them in studying music [13]. The description of this platform speaks about a virtual 'assistant teacher' concept for guidance when the student practices at home, giving additional feedback between sessions with the actual teacher.

VEMUS provides pedagogical tools for teachers based on the improvement of digital scores through graphic and audio annotations. The teacher can thus personalize the students' tasks by adding annotations in the score. Besides those, the teacher can make special annotations that are invisible to the student, thus selecting difficult passages that the VEMUS evaluation system can concentrate on.

The pedagogical approach of VEMUS is based on the concept of "extended music score" which offers new ways of feedback communication and improves the learning process. Feedback is accomplished by adding graphic shapes, text, emoticons, and audio annotations to the music score [14]. This approach includes various graphic representations of music performances displayed in the form of a feedback curve that runs parallel to the score. These enable the visualization of the student's performance and the explanation of such concepts as: attack, articulation, etc.

The VEMUS platform integrates a varied, rich content. It includes a repertoire of pieces and exercises, as well as non-interactive exercises concentrating on the quality of sound and warm-up exercises, devised by experts for each instrument. The expertise of theses teachers generated a musical material reflecting the international, as well as the local repertoire. According to the concept of VEMUS, the repertoire is organized on 5 main levels. On each level the repertoire is organized into lesson groups for a better characterization of the competences required for each element of learning. The evaluation procedure of VEMUS included schools in Sweden, Greece, Romania, and Lithuania, completed by validation activities in Estonia. In this way an evaluation procedure was contrived which used student groups in order to determine the effect of employing VEMUS in music education as compared to control groups.

During the project, the Romanian partner, specialized in designing software and in researching innovative educational techniques, subcontracted music institutions - AMGD and the Augustin Bena Music School - which performed and recorded the pieces in the software and subsequently tested its functionality with the assistance of teachers and students. An important issue consisted in evaluating the platform and offering a feedback from teachers and students on the impact of the software's inclusion in the individual instrument practice. We can summarize the benefits gained by the Romanian music institutions as follows: 
TABLE III

SYNTHESIS OF THE ACTIVITIES

\begin{tabular}{|c|c|c|}
\hline Project/goals & $\begin{array}{l}\text { AMGD's tasks } \\
\text { as } \\
\text { subcontracting } \\
\text { institution }\end{array}$ & Accomplishments \\
\hline $\begin{array}{l}\text { The VEMUS } \\
\text { platform integrated } \\
\text { innovative e- learning } \\
\text { components for: } \\
\text { a) a self-practicing } \\
\text { environment with } \\
\text { evaluation and } \\
\text { feedback, } \\
\text { b) innovative tools for } \\
\text { teaching music in } \\
\text { groups of students by } \\
\text { supporting } \\
\text { collaborative } \\
\text { activities, } \\
\text { c) a distance learning } \\
\text { platform that couples } \\
\text { a content repository } \\
\text { with communication } \\
\text { and progress- } \\
\text { monitoring tools. }\end{array}$ & $\begin{array}{l}\text { - to organize } \\
\text { project } \\
\text { dissemination } \\
\text { - to create } \\
\text { samplers for } \\
\text { the recordings } \\
\text { in the software } \\
\text { (approximately } \\
500 \text { musical } \\
\text { examples) } \\
\text { - to conduct the } \\
\text { inquiry for } \\
\text { testing the } \\
\text { VEMUS } \\
\text { platform in } \\
\text { Cluj } \\
\text { (questionnaires } \\
\text { interviews). }\end{array}$ & $\begin{array}{l}\text { - endowment with } \\
\text { equipment } \\
\text { - organization in } \\
\text { AMGD of } 2 \\
\text { workshops in the } \\
\text { field of IT attended } \\
\text { by teachers from } \\
\text { various institutions, } \\
\text { - trips to meetings } \\
\text { within the VEMUS } \\
\text { project } \\
\text { - connecting to a } \\
\text { European network } \\
\text { and setting up a local } \\
\text { network, } \\
\text { - the appearance of } \\
\text { AMGD and the } \\
\text { partner Music School } \\
\text { on European } \\
\text { television (Euro } \\
\text { News coverage). }\end{array}$ \\
\hline
\end{tabular}

\section{E-VOCAL LEARNING}

The „e-vocal" project was enriched by the collaboration of professional Viennese musicians and resulted in a platform that can be used by music universities, music schools and adult education centers interested in classical singing, facilitating the assimilation of a very consistent repertoire.

Due to the rich database created we sought both to increase the technical level and to overcome the problems linked to the assimilation of multiple styles in training a singer for stage performance. The goal was to facilitate the following technical elements: correct position, centering and breath control, mastering basic knowledge of sight reading a vocal score, correct performance of the vocal repertoire, clear articulation, achieving adequate dynamics. We started from the identification of the practicing requests of vocal materials and the explanation of a variety of styles: classic singing, musical theatre, contemporary music [13]. By downloading a video file of a music aria one can simulate a rehearsal in which the student is guided to sing the piece according to the indications and tempo of the virtual conductor. http://www.e-vocal.com

The learning program E-vocal learning includes:

a. Videos with conductors (a video with piano and voice and one just with piano for each aria); this exercise involves cooperation with a conductor, highlighting the rigors and difficulties of each particular piece;

b. Language, phonetics, and rhythm exercises focusing on the necessities of text performance, practiced by uttering the verses to the music's rhythm. For Italian, this task was entrusted to an experienced prompter from the Vienna State Opera;
3. The on-line platform for the learning of a repertoire appropriate for various voice types: soprano, alto, tenor, bass;

d. DVDs for offline learning, so that the database may also be used when no internet connection is available; all conductors' videos and the mp3 verse files are available on the "Learning-DVDs for singers". There are 10 DVDs published by C. F. Peters (www.edition-peters.de) since 2009.

The E-vocal learning platform is an educational resource with the following features:

- attractive design and easy downloading of conductors' videos and of mp3 verse files, as well as easy notation-Plug-In installation;

- it is readily extensible and enables the facile addition of new multimedia learning and training materials;

- it enables the access of various user types: teachers, students, and administrators;

- it offers varied communication opportunities: forums, message sites, contact forms, newsletter;

- it keeps a learning $\log$ in order to follow the educational process and to assist the teacher in monitoring the student's progress.

All through its development, the project was supervised by an external evaluator and tested within the distance learning system of AMGD. By applying qualitative interviewing techniques we performed an analysis of the environment where the project took place and applied individual corrections in the students' progress or collective corrections in building the platform.

TABLE IV

E-VOCAL CONTENT

\begin{tabular}{|c|c|c|}
\hline Project content & $\begin{array}{l}\text { Trained human } \\
\text { resource }\end{array}$ & $\begin{array}{l}\text { AMGD's } \\
\text { tasks/achievements }\end{array}$ \\
\hline $\begin{array}{l}\text { e-learning } \\
\text { platform for } \\
\text { singing } \\
\text { comprising: } \\
\text { conductors' } \\
\text { videos, language } \\
\text { and phonetic } \\
\text { exercises to the } \\
\text { rhythm of arias in } \\
\text { the repertoire, } \\
\text { DVDs with the } \\
\text { project repertoire. }\end{array}$ & $\begin{array}{l}\text { - approximately } \\
120 \text { students } \\
\text { from AMGD } \\
\text {-10 singing } \\
\text { teachers } \\
\text { - IT staff of } \\
\text { AMGD's } \\
\text { Distance } \\
\text { Learning } \\
\text { Department }\end{array}$ & $\begin{array}{l}\text { - product testing by the } \\
\text { students } \\
\text { - access to a database of } \\
\text { musical examples } \\
\text { (accompaniment music) } \\
\text { necessary to singers } \\
\text { - the distance learning } \\
\text { (singing) students and } 10 \\
\text { teachers were signed up } \\
\text { (for a limited time) on the } \\
\text { e-vocal platform } \\
\text { - the use of the platform } \\
\text { in the distance learning } \\
\text { program as an educational } \\
\text { resource }\end{array}$ \\
\hline
\end{tabular}

\section{DIRECT IMPACT MULTIMEDIA APPLICATION (DIMA)}

As an outcome of the collaboration in the above mentioned European projects, AMGD applied for a European financing through the entity named the Executive Financing Unit of Higher Education in Romania for a project that sought to integrate multimedia resources in music education. Due to this project we created a specially adapted e-learning platform comprising: training facilities, support in using and integrating ICT in a flexible curriculum, the thematic 
systematization of music terms in an on-line glossary of music terminology.

The teaching staff involved in developing the DIMA platform received training for creating, implementing, and using the resources on the DIMA platform and were offered specific guides on developing courses in e-form and on using the platform. These steps were preceded by an inquiry among the students enrolled in AMGD's educational programs, which showed that they were interested in using on-line educational resources. Students use the internet for accessing new information, thus motivating the necessity to create a database specific for the field of music:

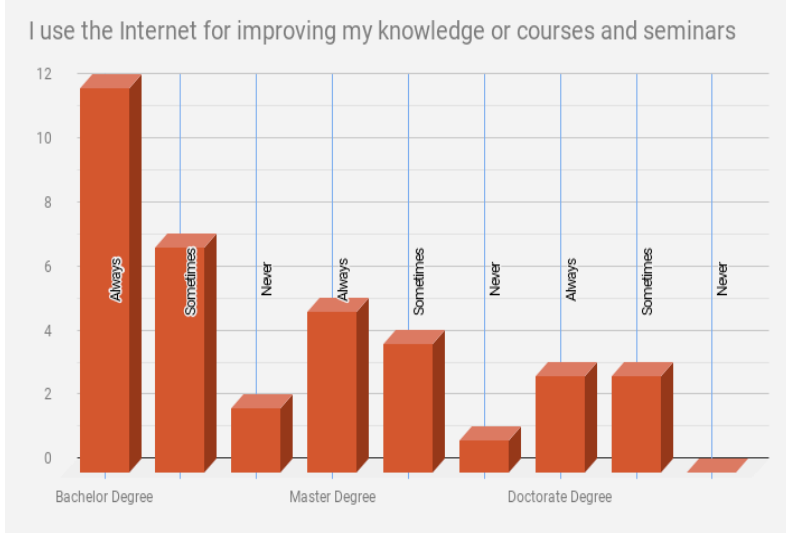

Figure 4. The level to which information is accessed on-line

There is a broad range of technologies that were used to address curriculum requests and to connect with other users.

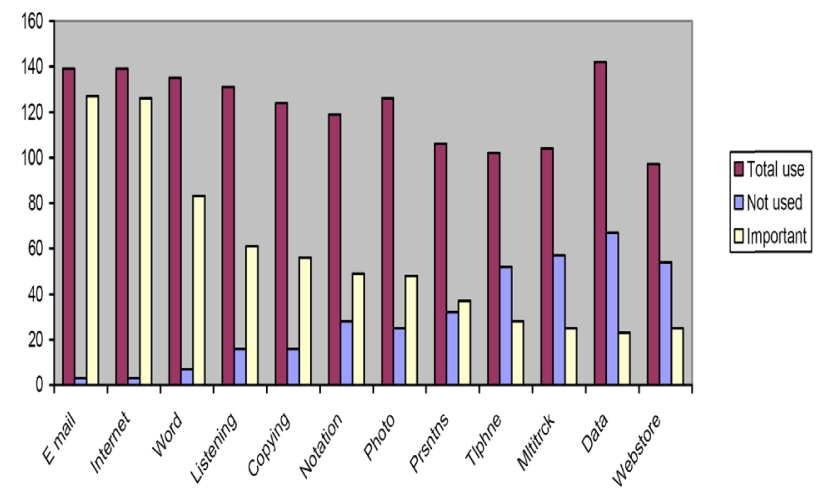

Figure 5. The type of technology employed

The surveys conducted in the Department of Distance Learning of the Academy of Music Gheorghe Dima in Cluj-Napoca revealed a series of issues linked to the students' needs of accessing educational materials and literature; however, the students expressed their desire to learn through information exchanges within the learning community and to get easier access to the curriculum content through on-line tutoring:

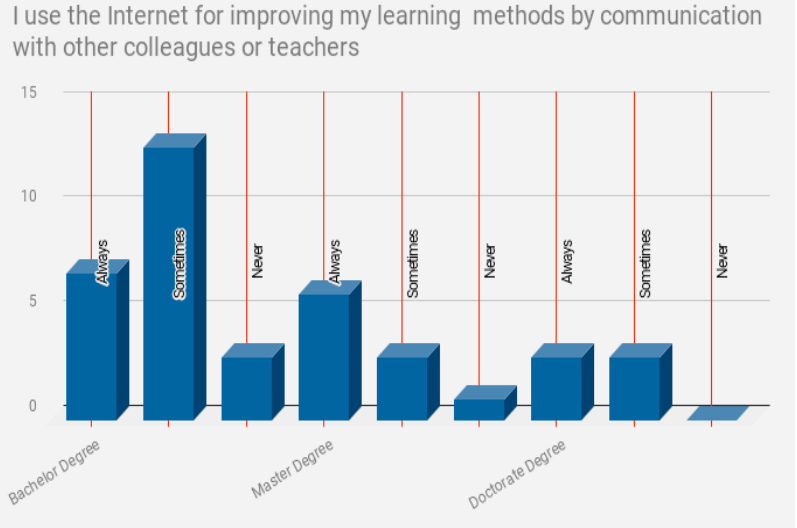

Figure 6. Assessment of the curriculum content presentation

The starting point of the project that created the distance learning platform was the requests expressed by the students, who were involved in drafting certain training materials on the platform and, along with an entity specialized in IT, the Ecological Informatics Society, had an active share in creating the electronic DIMA platform. The entire teaching staff of the academy contributed to the terminological glossary, so that the musical terms and expressions are now available in multimedia format on the platform dedicated to the distance learning program (http://decid.amgd.ro/dima), where new multimedia terminology fields can be created for those who wish to contribute to the development of the existing database. The basic fund of the musical glossary comprises the following sections:

- Instruments and singing (keyboard, string, wind, and percussion instruments, singing), being made up of: scores, performance examples, audio and video examples, clues for technical solutions, stylistic incursions;

- Composers and music styles: systematizations according to stylistic stages, audio and video examples, scores, references;

- Musical theories and applications for such subjects as music theory, harmony, counterpoint, folklore, aesthetics, dramaturgy, by means of scores and audio/video/text examples;

- Information and communication technologies in music and presentation of reference points in electronic music technology.

- Theoretical guide for creating multimedia applications including: training in multimedia, Sibelius, and Audacity.

After the conclusion of the construction process of the distance learning system used in AMGD, based on an electronic platform with multiple functionalities, we created a system that enables us to monitor its use by means of a questionnaire for users (full-time and distance learning students, master students, doctoral students, as well as teaching staff). The questionnaire tested its usefulness, focusing on: competence in using on-line resources, access to electronic information and to computerized infrastructure, IT-supported methods of music education, learning mediated by accessible technologies, integration of multimedia resources into music education. The outcomes highlighted a significantly improved level of IT use by musicians: ICT is regarded as 
a tool to support teachers in accomplishing the following tasks:

- improving the lesson design through learning platforms;

- developing tools and resources;

- engaging and motivating students;

- providing opportunities for students to learn in alternative and challenging ways;

- enabling both collaborative and individual work;

- providing access to sources of information by searching educational websites on the internet;

- helping students to investigate new musical alternatives;

- helping students to review, refine, redraft and modify work;

- assisting students in refining their performances, compositional or learning skills.

TABLE V

SYNTHESIS OF DIMA OUTPUTS

\begin{tabular}{|c|c|}
\hline Project & Achievements \\
\hline $\begin{array}{l}\text { DIMA } \\
\text {-creating a multimedia } \\
\text { platform (DIMA) } \\
\text {-creating courses in } \\
\text { multimedia format } \\
\text {-editing a guide of } \\
\text { good practice } \\
\text { issued in electronic and } \\
\text { classic form }\end{array}$ & $\begin{array}{l}\text {-training the teaching staff in } \\
\text { creating video/audio materials } \\
\text {-creating a systemized database of } \\
\text { musical terms } \\
\text {-creating an international magazine } \\
\text { called ICT in Musical Field } \\
\text {-stimulation of scientific research } \\
\text { by publishing articles and research } \\
\text { papers by members of the project in } \\
\text { specialized magazines/conferences }\end{array}$ \\
\hline
\end{tabular}

\section{CONCLUSIONS}

The co-work in European networks resulted in the construction of our own distance learning system in AMGD [15]. and in finding solutions for a broad range of requests. In order to stress the practical relevance of collaboration within European networks, the gain in experience and the access to financing through European projects, we point out several of the benefits:

- The Prelude project offered: development of the teaching staff competence in IT, an imperative in the field of music, strengthening skills in using and even creating on-line teaching resources, assuring a wide access to informational resources (that is, to European platforms) and linking the Romanian music education system to the systems in other European countries [16].

-Using the VEMUS Platform relies on the active participation of music teachers, a base of activity that caused the construction of a local network between AMGD and music schools in the city. The interest shown by the children and parents who took part in the project demonstrated the opportunity of introducing ICT in music education in Romania.

-E-Vocal stimulated the use of multimedia resources, especially in the field of performance education, a field that is not easily accepted by specialists for on-line education. The examples of developing e-learning modules through MP3 multimedia formats and video learning systems, such as piano accompaniments, spoken texts of arias in their original language, or films with conductors, so as to offer students the occasion to learn from professionals' performances, and to participate in simulated rehearsals offered starting points in drafting AMGD's own multimedia anthology. The access to this platform consisting of recorded examples with renowned musicians of the Vienna Opera was initially free of charge for our students; it is currently used, in return for payment, by numerous students. They can interact, at home or at school, with the conductor, with singing techniques and with the musical and linguistic/phonetic characteristics of the arias.

In the DIMA project, the results of the preliminary inquiry confirmed the necessity of building a platform for the academy, as well as the need to render the educational content more accessible and to continue to organize training courses in IT, particularly for teachers. The platform that resulted meets the curricular necessities of AMGD, in on-line format, and, according to evaluations, improves the level of information assimilation, and stimulates the subjects' interest for accessing information.

As soon as the electronic platform of the Distance Learning Department became available, as a quality standard of the distance learning system, the students had access, through the offered facilities, to one of the most complex work instruments in the field of music, an on-line educational resource accompanied by a multimedia application called D.I.M.A. (Direct Impact Multimedia Application). This is an on-line terminology glossary for information and study that was implemented for and especially adapted to music education.

\section{REFERENCES}

[1] T.D. Chicioreanu, " The integration of e-learning platforms in the teaching activities", ICTMF, vol.VI, no.1, 2015, pp.7-17.

[2] N. Breeze, "Learning design and proscription: how generative activity was promoted in music composing", International Journal Of Music Education, vol. 27, nr. 3, 2009, pp. 204-219. https://doi.org/10.1177/0255761409335953

[3] C. Byrne and R.A.R. MacDonald, "The Use of Information and Communication Technology (I\&CT) in the Scottish Music Curriculum: a Focus Group Investigation of Themes and Issues", Music Education Research, Vol. 4, No. 2, 2002, pp. 263-273. https://doi.org/10.1080/1461380022000011957

[4] J. Mills, and A. Murray, "Music Technology Inspected: Good Teaching in Key Stage 3", British Journal of Music Education, Vol. 17, 2000, pp. 129-156. https://doi.org/10.1017/S02650 $5170000022 \mathrm{X}$

[5] B. Crow, "Music-related ICT in education", in C. Philpott (Ed.), Learning to Teach Music in the Secondary School, London: Routledge/Falmer, 2001, pp. 135-162.

[6] J.R. Austin and M. Haefner Berg, "Exploring Music Practice among Sixth-Grade Band and Orchestra Students", Psychology of Music, Vol. 34, No. 4, 2006, pp. 535-558. https://doi.org/10.1177/ 0305735606067170

[7] E. Yung, N. Nedelcuț, "Scalebook and Vemus, literacy software tool", ICTMF, vol. VII, no.2, 2016, pp. 37-42.

[8] M .Popean, "Cycling '74 Max, o platformă educațională intercurriculară", ICTMF, Vol. VII, no.1, 2016, pp.7-17.

[9] P.R. Webster, "Computer-based Technology and Music Teaching and Learning: 2000-2005", International Handbook of Research in Arts Education, L. Bresler (Ed.), Springer, 2007, pp. 13111328. https://doi.org/10.1007/978-1-4020-3052-9_90

[10] Y. Ju Joo, S. Joung, H. S. Son, "Structural relationships among effective factors on e-learners' motivation for skill transfer", Computers in Human Behavior, vol. 32, Issue null, 2013, pp. 335342. 
[11] D. Fober, S. Letz and Y. Orlarey, "VEMUS - Feedback and Groupware Technologies for Music Instrument Learning", Proceedings SMC'07, 4th Sound and Music Computing Conference, Lefkada, Greece, July 2007, pp.117-123.

[12] S. Raptis, A. Chalamandaris, A. Baxevanis, A. Askenfelt, E. Schoonderwaldt, K. Falkenberg Hansen, D. Fober, S. Letz, and Y. Orlarey, "IMUTUS - an Effective Practicing Environment for Music Tuition", ICMC-2005 Conference Proceedings, pp. 383Conference on Creativity \& Cognition, April 2005, pp. 166- 175.

[13] J. Walding, "E-vocal com: e-learning in classical vocal training, an educational platform for singers", ICTMF, vol II, nr.1, 2011, pp 71-74.

[14] D. Fober, S. Letz, Y. Orlarey, A. Askenfelt, K. Falkenberg Hansen, and E. Schoonderwaldt, "IMUTUS - an Interactive Music Tuition System", Proceedings of the SMC'04 Conference, IRCAM 2004, pp. 97-103.

[15] N.Nedelcut, C.G.Pop, "The Electronic Platform - A Multifunctional Tool of Distance Learning", ICTMF, vol VI, no 2, 2015, pp. 39-48.

[16] "Prelude Training Program on ICT in Music", Trainees' guide; Student Platform Manual; Final report on teachers' needs analysis, No. I129282-CP-1-2006-1-GR-COMENIUS-C2, unpublished.

\section{AUTHORS}

Nelida Nedelcut is with the Academy of Music "Gheorghe Dima", Cluj-Napoca, 400079, I.C. Bratianu street, Nr. 25, ROMANIA (e-mail: nelida.nedelcut@, amgd.ro).

Ciprian Gabriel Pop is with the Academy of Music "Gheorghe Dima", Cluj-Napoca, 400079, I.C. Bratianu street, Nr. 25, ROMANIA (e-mail: ciprian.pop@ amgd.ro).

Amalia Cristina Nedelcuț is with the Babes-Bolyai University, Faculty of Economics and Business Administration/Management Department, Cluj-Napoca, 400591, Teodor Mihali street, Nr.58-60. ROMANIA (email: amalianedelcut@gmail.com).

Manuscript received 12 March 2018.

Published as submitted by the author(s). 